\title{
TYTUŁ PRAWNY DO SKŁADOWISKA ODPADÓW
}

\author{
LEGAL TITLE TO A LANDFILL
}

http://dx.doi.org/10.12775/PPOS.2015.039

\section{STRESZCZENIE}

Celem opracowania jest analiza „tytułu prawnego” nieruchomości, na której znajduje się składowisko odpadów. Następnie ustalić należy, czy, i jeżeli tak - to jaki, tytuł prawny jest wymagany do prowadzenia składowiska odpadów, począwszy od chwili jego założenia do etapu eksploatacji. Analizowane zagadnienie ma istotne znaczenie dla problematyki egzekwowania na prowadzącym składowisko odpadów ciążących na nim obowiązków.

\section{Słowa kluczowe}

Tytuł prawny; składowisko odpadów; prawo o odpadach.

* Pracownik Katedry Prawa Administracyjnego Uniwersytetu Mikołaja Kopernika w Toruniu, radca prawny.

** Członek pozaetatowy Samorządowego Kolegium Odwoławczego w Toruniu, radca prawny. 


\section{ABSTRACT}

The aim of this article is to analyse the "legal title" of a real property on which a landfill is located. Firstly, it must be established who is under obligation to hold such a title, concerning the phase of landfill's exploitation. Secondly, it must be examined what kind of a legal title is required for the obliged person. The analysed issue may determine the possibility of execution of the landfill owner's obligations.

\section{Keywords}

Legal title; landfill; waste law.

\section{WPROWADZENIE}

Ustawa o odpadach ${ }^{1}$ nałożyła na zarządzającego składowiskiem odpadów obowiązek posiadania tytułu prawnego do całej nieruchomości, na której znajduje się składowisko odpadów, wraz ze wszystkimi instalacjami i urządzeniami związanymi z prowadzeniem tego składowiska, w okresie obejmującym fazę eksploatacyjną i poeksploatacyjną (art. 124 ust. 1 u.o.).

Wartym rozważenia jest ustalenie istnienia obowiązku legitymowania się tytułem prawnym i jego zakresem w odniesieniu do lokalizacji, budowy i prowadzenia składowiska odpadów. Przede wszystkim wyjaśnienia wymaga zakres użytego terminu „tytułu prawnego do nieruchomości”, który ma przysługiwać prowadzącemu składowisko celem wykonywania działalności zgodnie z wymogami.

Ustawa nie zawiera autonomicznej definicji pojęcia „tytułu prawnego”. Przyjmując, że „zbiór norm obowiązujących w danym państwie powinien być spójny i uporządkowany"2, to - wobec braku uregulowania powyższej kwestii bezpośrednio w ustawie szczegółowej - należy ustalić znaczenie użytego

1 Ustawa z dnia 14 grudnia 2012 r. o odpadach, Dz.U. z 2013 r., poz. 21 ze zm. (dalej cyt.: u.o. lub ustawa).

2 L. Morawski, Zasady wykładni prawa, Toruń 2006, s. 109. 
terminu w odniesieniu do norm wchodzących w skład szeroko rozumianego systemu ochrony środowiska. Za taką możliwością zdają się także przemawiać poglądy literatury ${ }^{3}$, które uznają, że ustawa stanowi część systemu prawa ochrony środowiska i nie narusza postanowień ustawy Prawo ochrony środowiska. Oznacza to, że uprawnionym jest stosowanie definicji pojęć zawartych w u.p.o.ś., które nie posiadają samodzielnego znaczenia nadanego w ustawie.

Zasadnym zatem jest zastosowanie przepisu art. 3 pkt 41 ustawy Prawo ochrony środowiska ${ }^{4} \mathrm{w}$ celu dookreślenia znaczenia pojęcia „tytuł prawny”. Zgodnie z powyższym przepisem „tytułem prawnym” jest prawo własności, użytkowanie wieczyste, trwały zarząd, ograniczone prawo rzeczowe albo stosunek zobowiązaniowy. Celem niniejszych rozważań jest analiza, czy, i jeżeli tak - to jaki, tytuł prawny jest wymagany do prowadzenia składowiska odpadów, począwszy od chwili jego założenia do etapu eksploatacji.

\section{LOKALIZACJA SKŁADOWISKA}

Pierwszym etapem procesu inwestycyjnego, prowadzącym do powstania składowiska odpadów, jest spełnienie warunków wynikających z ustawy o planowaniu i zagospodarowaniu przestrzennym ${ }^{5}$, przy uwzględnieniu uwarunkowań wynikających z przepisów szczególnych ${ }^{6}$.

Lokalizacja składowiska może nastąpić w oparciu o ustalenia miejscowego planu zagospodarowania przestrzennego.

3 K. Karpus, Komentarz do art.124 ustawy o odpadach, stan prawny: 2013.09.15 eLex; W. Radecki, Komentarz do art.124 ustawy o odpadach, stan prawny: 2013.06.01 eLex.

4 Ustawa z dnia 27 kwietnia 2001 r. Prawo ochrony środowiska, t.j. Dz.U. z 2013 r., poz. 1232 ze zm. (dalej cyt.: u.p.o.ś.).

5 Ustawa z dnia 27 marca 2003 r. o planowaniu i zagospodarowaniu przestrzennym, t.j. Dz.U. z 2015 r., poz. 199 ze zm. (dalej cyt.: u.p.z.p.).

6 Rozporządzenie Ministra Środowiska z dnia 30 kwietnia 2013 r. w sprawie składowisk odpadów (Dz.U. z 2013 r., poz. 523). 
W takiej sytuacji oczywistym jest, że ustalenia tego planu, jako aktu prawa miejscowego, tworzone są niezależnie od przysługujących uprawnień właścicielskich.

Natomiast sytuacja nie jest już klarowna, gdy lokalizacja składowiska następuje w oparciu o decyzję lokalizacyjną. Prawną możliwość lokalizacji składowiska odpadów na podstawie aktu administracyjnego wprost przewiduje przepis art. 52 ust. 2 pkt 3 u.p.z.p. Właściwą dla lokalizacji składowiska odpadów jest decyzja ustalająca lokalizację inwestycji celu publicznego. Lokalizacja składowiska odpadów jest bowiem celem publicznym $\mathrm{w}$ rozumieniu ustawy o gospodarce nieruchomościami ${ }^{7}$ (art. 6 ust. 3 u.g.n.).

W świetle ustawy o planowaniu i zagospodarowaniu przestrzennym decyzję o lokalizacji inwestycji celu publicznego wydaje się dla celów publicznych w rozumieniu przepisów ustawy o gospodarce nieruchomościami (art. 2 pkt 5 u.p.z.p.) ${ }^{8}$. Sama ustawa o planowaniu i zagospodarowaniu przestrzennym przewiduje odrębne, inne niż w odniesieniu do innych inwestycji celu publicznego, wymogi wniosku wszczynającego postępowanie w sprawie wydania decyzji o inwestycji celu publicznego dla przedsięwzięcia w postaci składowiska odpadów.

W przypadku decyzji lokalizacyjnej dotyczącej budowy składowiska odpadów wymagane jest określenie docelowej rzędnej składowiska odpadów, rocznej i całkowitej ilości składowanych odpadów oraz rodzajów składowanych odpadów, a także sposobu gromadzenia, oczyszczania i odprowadzania ścieków oraz sposobu gromadzenia, oczyszczania i wykorzystywania lub unieszkodliwiania gazu składowiskowego.

Bezspornym jest, że dla wydania decyzji lokalizacyjnej nie jest wymagany tytuł prawny do nieruchomości. Przewiduje ona tylko potencjalną możliwość realizacji takiego przedsięwzięcia, nie zaś faktyczne jego wykonanie. Jest ona pierwszym etapem w czynnościach administracyjnych zmierzających do realizacji inwestycji w przypadkach, kiedy zostaną spełnione szczegółowe

7 Ustawa z dnia 21 sierpnia 1997 r. o gospodarce nieruchomościami, t.j. Dz.U. z 2015 r., poz. 1774 ze zm. (dalej cyt.: u.g.n.).

8 Art. 2 pkt 5 u.p.z.p. 
warunki wynikające przede wszystkim z przepisów prawa budowlanego. W judykaturze wręcz podnosi się, że „decyzja o warunkach zabudowy jest jedynie promesą lokalizacji inwestycji na danej działce a szczegółowe ustalenia następują $\mathrm{w}$ decyzji o pozwoleniu na budowę" 9 .

Należy zwrócić uwagę, że szczegółowe wymagania względem ustawy o planowaniu i zagospodarowaniu przestrzennym wynikają z przepisów ustawy o odpadach. Wprowadzono, obok „zwykłych" uzgodnień wynikających z ustawy o planowaniu i zagospodarowaniu przestrzennym, konieczność uzyskania zgody dyrektora regionalnego zarządu gospodarki wodnej w zakresie związanym z ochroną wód dla lokalizacji składowiska (art. 126 ust. 1 u.o.). Natomiast wyznaczenie lokalizacji składowiska odpadów: 1) w pobliżu lotnisk - wymaga zgody organów administracji lotniczej; 2) w pobliżu obiektów zabytkowych lub na terenie, na którym znajdują się zabytki archeologiczne - wymaga zgody wojewódzkiego konserwatora zabytków; 3) w obszarze pasa nadbrzeżnego oraz portów i przystani morskich - wymaga zgody dyrektora urzędu morskiego (art. 126 ust. 2 u.o.).

Brak uzyskania zgody wymienionych powyższej organów stanowi negatywną przesłankę uzyskania decyzji lokalizacyjnej. Nie są to jednak okoliczności wpływające na tytuł prawny do nieruchomości, na której ma zostać zlokalizowane składowisko. Dokonana analiza regulacji prawnej wskazuje, że na etapie lokalizacji składowiska odpadów nie jest wymagany jakikolwiek tytuł prawny do nieruchomości celem lokalizacji takiej inwestycji. Taki wymóg nie wynika bowiem ani z przepisów ustawy o planowaniu i zagospodarowaniu przestrzennym, ani z ustawy o odpadach.

9 Wyrok WSA w Bydgoszczy z dnia 17 grudnia 2014 r., II SA/Bd 1005/14, CBOSA, podobnie WSA w Poznaniu z dnia 29 stycznia 2014 r., IV SA/Po 799/13, CBOSA. 


\section{BUDOWA SKEADOWISKA}

Odmienna sytuacja występuje w odniesieniu do faktycznej realizacji inwestycji na podstawie przepisów ustawy Prawo budowane ${ }^{10}$. Składowisko odpadów zaliczane jest do budowli (art. 3 pkt 3 u.p.b.), na wzniesienie której wymagane jest uzyskanie pozwolenia na budowę (art. 28 ust. 1 u.p.b.).

Na etapie tego postępowania inwestor powinien legitymować się tytułem prawnym do dysponowania nieruchomością na cele budowlane. Wymóg ten wynika z przepisu art. 32 ust. 4 pkt 2 u.p.b. Szczegółową regulację w tym zakresie, zbieżną $\mathrm{z}$ postanowieniami ustawy Prawo budowlane, zawiera przepis art. 127 ust. 2 ustawy, zgodnie z którym do wniosku o udzielenie pozwolenia na budowę należy dołączyć oświadczenie o posiadanym tytule prawnym do dysponowania całą nieruchomością, na której będzie zlokalizowane składowisko odpadów wraz ze wszystkimi instalacjami i urządzeniami, związanymi z prowadzeniem tego składowiska odpadów, w okresie obejmującym fazę eksploatacyjną i poeksploatacyjną.

Ustawa Prawo budowlane w sposób autonomiczny reguluje pojęcie prawa do dysponowania nieruchomością na cele budowlane. Jest nim bowiem tytuł prawny wynikający z prawa własności, użytkowania wieczystego, zarządu, ograniczonego prawa rzeczowego albo stosunku zobowiązaniowego, przewidującego uprawnienia do wykonywania robót budowlanych (art. 3 pkt 11 u.p.b.). W tym zakresie powyższy przepis wydaje się być zbieżny z definicją tytułu prawnego zawartą w przepisie art. 3 pkt 41 u.p.o.ś. Można więc stwierdzić, że regulacja wynikająca z przepisów ustawy o odpadach stanowi superfluum względem ustawy Prawo budowlane.

Oznacza to, że przed przystąpieniem do realizacji inwestycji, polegającej na budowie składowiska odpadów, inwestor każdorazowo jest zobowiązany do posiadania tytułu prawnego umożliwiającego przeprowadzenie przedsięwzięcia. Prze-

10 Ustawa z dnia 7 lipca 1994 r. Prawo budowlane, t.j. Dz.U. z 2013 r., poz. 1409 ze zm. (dalej cyt.: u.p.b.). 
pisy ustawy Prawo budowlane nie wymagają w tym zakresie szczegółowego udokumentowania tytułu prawnego, lecz wystarczające jest oświadczenie inwestora składane pod rygorem odpowiedzialności karnej. W przypadku wątpliwości organu administracji okoliczność legitymowania się odpowiednim tytułem prawnym może stanowić część postępowania wyjaśniającego. Za powyższym poglądem opowiedziała się także judykatura. WSA w Krakowie w powyższym zakresie zauważył, że: „gdy prawo do dysponowania nieruchomością na cele budowlane kwestionowane jest $\mathrm{w}$ toku postępowania przez inną osobę, organ zobowiązany jest tę kwestię wyjaśnić nie poprzestając wyłącznie na odnotowaniu faktu złożenia oświadczenia o dysponowaniu nieruchomością na cele budowlane, a szczególny obowiązek spoczywa w tym zakresie na inwestorze"11.

Roboty budowlane mogą zostać rozpoczęte po uzyskaniu wykonalnej decyzji o udzieleniu pozwolenia na budowę. Należy dostrzec, że od 28 czerwca 2015 r. obowiązuje przepis art. 28 ust. 1 ustawy Prawo budowlanego w brzmieniu znowelizowanym $^{12}$, który nie przewiduje konieczności, aby decyzja ta była ostateczna. W konsekwencji pozwolenie na budowę powinno być wykonalne w rozumieniu przepisów Kodeksu postępowania administracyjnego (art. 130 k.p.a.).

$\mathrm{Na}$ etapie uzyskania pozwolenia na budowę nieuzasadnionym jest złożenie oświadczenia o posiadanym tytule prawnym do dysponowania instalacjami i urządzeniami, związanymi z prowadzeniem tego składowiska odpadów, w okresie obejmującym fazę eksploatacyjną i poeksploatacyjną. Trudno jest bowiem na tym etapie procesu inwestycyjnego przewidzieć jakie uwarunkowania będą dotyczyć instalacji i urządzeń, które powstaną w przyszłości. Inwestor, zmierzając do wybudowania składowiska odpadów, nie musi bowiem przewidywać co nastąpi w przyszłości, zwłaszcza na etapie likwidacji składowiska odpadów, które nawet jeszcze nie powstało. Wszystkie jego działania

11 Wyrok WSA w Krakowie z dnia 5 marca 2013 r., II SA/Kr 1766/12, CBOSA.

12 Ustawa z dnia 20 lutego 2015 r. o zmianie ustawy Prawo budowlane oraz niektórych innych ustaw, Dz.U. z 2015 r., poz. 443. 
w tym zakresie mogą mieć charakter jedynie przewidywań i nie sposób je skonkretyzować dla potrzeb uzyskania pozwolenia na budowę. Wprowadzenie wymogu złożenia oświadczenia w tak szerokim zakresie nie jest uzasadnione, bowiem poszczególne elementy składowiska mogą powstawać etapami i dopiero wtedy istnieje potrzeba ich konkretyzacji, a co za tym idzie - dysponowania odpowiednim tytułem prawnym.

$\mathrm{Na}$ etapie pozwolenia na budowę, oświadczenie o posiadanym tytule prawnym do dysponowania całą nieruchomością, na której będzie zlokalizowane składowisko odpadów, wraz ze wszystkimi instalacjami i urządzeniami, związanymi z prowadzeniem tego składowiska odpadów, w okresie obejmującym fazę eksploatacyjną i poeksploatacyjną, dotyczy nieruchomości, na którym ma powstać składowisko odpadów. W tym zakresie tytuł prawny w rozumieniu ustawy powinien być analogiczny, jak w rozumieniu ustawy Prawo budowlane.

\section{PROWADZENIE SKŁADOWISKA}

Przed przystąpieniem do użytkowania składowiska odpadów koniecznym jest uzyskanie decyzji o pozwoleniu na użytkowanie. Wymóg ten wynika z przepisu art. 55 ust. 1 pkt 1 lit. e ustawy Prawo budowlane, jako że składowiska odpadów zostały zaliczone do kategorii XXII obiektów budowlanych, zaś na budowę wymagane jest pozwolenie na budowę.

Zakres obowiązku posiadania prawa („tytułu prawnego”) został wyznaczony przez nieruchomość, na której zlokalizowane jest składowisko odpadów wraz ze wszystkimi instalacjami i urządzeniami związanymi z prowadzeniem tego składowiska. Zdaniem autorów obowiązujące przepisy nie normują natomiast obowiązku posiadania tytułu prawnego do instalacji i urządzeń związanych z prowadzeniem składowiska odpadów.

Odmienne wnioski wynikają z lektury uzasadnienia projektu ustawy, gdzie wskazuje się, że „nałożenie obowiązku posiadania tytułu prawnego do całej nieruchomości oraz urządzeń 4/2015 ma na celu uniknięcie sytuacji, w której różne podmioty zarzą- 
dzają np. składowiskiem odpadów i instalacją np. do odgazowania składowiska, a w rezultacie tego powstają trudności w egzekwowaniu przepisów obowiązującego prawa oraz warunków prowadzenia działalności określonych w prawomocnych decyzjach administracyjnych. Zarządzający składowiskiem odpadów ponosi bowiem odpowiedzialność za całokształt działalności składowiska odpadów"13. Z przedstawionego uzasadnienia wynika, że celem wprowadzonej regulacji jest zapewnienie możliwości realizowania obowiązków zarządzającego składowiskiem odpadów wynikających bezpośrednio z przepisów prawa.

Wprowadzona regulacja nie zakazuje jednak zawierania przez zarządzającego składowiskiem odpadów umów związanych z wykorzystywaniem nieruchomości (lub jej części), na której zlokalizowane jest składowisko, z innymi podmiotami. Brak jest normy prawnej, która zakazywałaby zawierania takich umów czy też przewidywała sankcję za ich zawarcie. Należy poczynić jednak zastrzeżenie, że ewentualne ograniczenia wynikające z zawieranych umów nie powinny doprowadzić do uniemożliwienia wykonywania ustawowych obowiązków zarządzającego składowiskiem.

Wobec powyższego należy zadać pytanie, czy rzeczywiście tytuł prawny prowadzącego składowisko odpadów powinien się ograniczać tylko do nieruchomości, czy też rozciągać się również na wszystkie instalacje i urządzenia związane z prowadzeniem tego składowiska. Należy więc ustalić zakres poszczególnych elementów składowiska wynikających z przepisu art. 124 ust. 1 u.o., czyli dookreślić czym jest instalacja, a czym urządzenie związane z prowadzeniem składowiska.

Instalacją w rozumieniu u.p.o.ś. są: stacjonarne urządzenie techniczne, zespół stacjonarnych urządzeń technicznych powiązanych technologicznie, do których tytułem prawnym dysponuje ten sam podmiot i położonych na terenie jednego zakładu, a także budowle niebędące urządzeniami technicznymi ani ich zespołami. Każdorazowo niezbędnym jest, aby ich eksploatacja mogła spowodować emisję (art. 3 pkt 6 u.p.o.ś.).

13 Druk sejmowy nr 456 z dnia 28 maja 2012 r., s. 60-61 uzasadnienia projektu ustawy o odpadach. 
Urządzeniami są natomiast niestacjonarne urządzenia techniczne, w tym środki transportu (art. 3 pkt 42 u.p.o.ś.).

Przepis art. 124 ust. 1 ustawy obejmuje zatem obie kategorie, co prowadzi do istotnych wniosków w kontekście jego interpretacji.

Możliwe wydają się dwie interpretacje. Pierwsza, prezentowana w uzasadnieniu projektu ustawy, która wiąże się z koniecznością posiadania tytułu prawnego nie tylko do nieruchomości, ale również do instalacji i urządzeń, które są związane z prowadzeniem składowiska. Druga interpretacja, która dopuszcza posiadanie tytułu prawnego tylko do nieruchomości, na której zlokalizowane jest składowisko odpadów. W takim przypadku odniesienie do instalacji i urządzeń służy skonkretyzowaniu nieruchomości, na której one się znajdują, a nie wyznacza zakresu przedmiotowego tytułu prawnego.

Zgodnie $\mathrm{z}$ pierwszym stanowiskiem prowadzący składowisko odpadów zawsze musiałby posiadać tytuł prawny do wszystkich instalacji i urządzeń związanych z jego prowadzeniem. Biorąc pod uwagę, że środki transportu są urządzeniami, niemożliwym byłoby zlecenie przez prowadzącego składowisko świadczenia jakichkolwiek usług przez osobę trzecią w zakresie, w jakim związane są one z korzystaniem z instalacji i urządzeń. Zawarcie umowy o świadczenie usług nie tworzy bowiem po stronie zleceniodawcy tytułu prawnego do instalacji i urządzeń, z których korzysta zleceniobiorca. Prowadziłoby to do wniosku, że możliwym jest zlecenie wykonania określonych usług osobie trzeciej, o ile jednak korzysta ona z instalacji i urządzeń, do których tytuł prawny przysługuje prowadzącemu składowisko (np. wykonanie przewozu przy użyciu samochodu prowadzącego składowisko).

Wydaje się, że taka interpretacja jest nieuprawniona, gdyż w nieuzasadniony sposób ograniczałaby możliwość faktycznego prowadzenia składowiska. Również względy celowościowe zdają się wykluczać przedstawioną interpretację, gdyż trudno upatrywać racjonalnych przesłanek w powiązaniu prowadzenia składowiska z tytułem prawnym do instalacji i urządzeń z nim związanych. Taki tytuł prawny bowiem nie jest konieczny do zgodnego z prawem prowadzenia składowiska odpadów, nie 
wpływa on na prawa i obowiązki prowadzącego składowisko. Sytuacja, w której świadczenie usług przez osobę trzecią mogłoby nastąpić wyłącznie z wykorzystaniem instalacji i urządzeń prowadzącego składowisko, zdaje się być również sprzeczna z powszechnie przyjętą praktyką gospodarczą.

Zasadnym jest więc przyjęcie drugiej z zaproponowanych interpretacji. Zgodnie $\mathrm{z}$ tym poglądem tytuł prawny powinien odnosić się tylko do całej nieruchomości i nie musi obejmować swym zakresem instalacji i urządzeń na niej zlokalizowanych. Takie podejście umożliwia wykonanie obowiązków ciążących na prowadzącym składowisko, wynikających z ustawy, i nie wprowadza szczegółowych ograniczeń związanych z jego prowadzeniem. W powyższym zakresie należy zwrócić uwagę na praktyczny walor zaprezentowanego poglądu. Dopuszcza ono bowiem wykorzystanie innych podmiotów oraz posiadanych przez nie instalacji i urządzeń do wykonywania czynności niezbędnych dla prowadzenia składowiska bez konieczności posiadania do nich tytułu prawnego przez prowadzącego składowisko. Stosunkowo nietrudno jest wyobrazić sobie sytuację, w której prowadzący składowisko korzysta z podmiotu zewnętrznego w celu zapewnienia wymaganego odgazowania składowiska przy wykorzystaniu instalacji i urządzeń wzniesionych przez podmiot zajmujący się odzyskiwaniem i przetwarzaniem gazu składowiskowego.

Sama literalna interpretacja przepisu art. 124 ust. 1 ustawy prowadzi do wniosku, że tytuł prawny odnosi się tylko do nieruchomości, a nie pozostałych elementów tworzących składowisko. Przyjmując postulat racjonalności ustawodawcy, konieczność posiadania tytułu prawnego także do instalacji i urządzeń wiązałaby się z innym brzmieniem przepisu. W takim przypadku przepis powinien brzmieć: „zarządzający składowiskiem odpadów posiada tytuł prawny do całej nieruchomości, na której znajduje się składowisko odpadów, i (oraz) do wszystkich instalacji i urządzeń związanych z prowadzeniem tego składowiska, w okresie obejmującym fazę eksploatacyjną i poeksploatacyjną", czego jednak ustawodawca nie uczynił.

Ponadto, jak już wskazano, ustawa posługuje się niedookreślonym pojęciem „tytuł prawny”, bez konkretnego wskaza- 
nia na czym ten tytuł ma polegać. Oznacza to, że dopuszczalnym jest zastosowanie wykładni celowościowej, zgodnie z którą jest możliwe korzystanie przez prowadzącego składowisko z przysługującego jemu tytułu prawnego, w tym zawierania umów mających na celu wykorzystanie składowiska, jeżeli nie rzutuje to na jego ustawowe obowiązki w zakresie prowadzenia takiego składowiska.

\section{PODSUMOWANIE}

Ustawa o odpadach wprowadziła konieczność posiadania tytułu prawnego do całej nieruchomości, na której znajduje się składowisko odpadów, wraz ze wszystkimi instalacjami i urządzeniami związanymi z prowadzeniem tego składowiska, w okresie obejmującym fazę eksploatacyjną i poeksploatacyjną, co wydaje się rozwiązaniem słusznym z uwagi na to, że jasno wskazuje jakie wymagania powinien spełnić prowadzący składowisko odpadów. Zauważyć jednak należy, że prowadzenie składowiska odpadów jest procesem długotrwałym, w czasie którego może dojść do zmiany sytuacji faktycznej lub prawnej związanej z prowadzącym składowisko odpadów. Natomiast składowisko odpadów może w trakcie jego prowadzenia ulegać dynamicznym przemianom, polegającym np. na jego rozbudowie. Taka sytuacja może doprowadzić do konieczności „wprowadzenia" na składowisko odpadów innych podmiotów, które wykonują czynności związane z jego prowadzeniem.

Powstaje wobec powyższego pytanie, czy koniecznym było wprowadzenie odrębnej regulacji dotyczącej tytułu prawnego do składowiska odpadów, podczas gdy, jak starano się wykazać, zakres tytułu prawnego może mieć różny charakter i zakres. Zależy on bowiem od tego jakie obowiązki nałożymy na prowadzącego składowisko. Natomiast samo posiadanie tytułu prawnego, które to pojęcie zawiera w sobie zarówno prawa rzeczowe, jak i prawa wynikające ze stosunków zobowiązaniowych, nie zawsze ułatwi możliwość faktycznego wyegzekwowa4/2015 nia na prowadzącym składowisko odpadów ciążących na nim 
obowiązków. Z kolei, jak wykazano w rozważaniach, na niektórych etapach procesu zmierzającego do zlokalizowania składowiska, taki tytuł nie jest wymagany.

\section{BIBLIOGRAFIA}

Karpus K., Komentarz do art. 124 ustawy o odpadach, LEX/el. 2013. Morawski L., Zasady wykładni prawa, Toruń 2006.

Radecki W., Komentarz do art. 124 ustawy o odpadach, LEX/el. 2013.

Kontakt e-mail:

brzoza@umk.pl 